\title{
PENERAPAN MEDIA ULAR TANGGA PADA MATERI LUAS DAN KELILING SEGITIGA
}

\author{
Malalina $^{1^{*}}$, Rika Firma Yenni ${ }^{2}$ \\ ${ }^{1,2}$ Pendidikan Matemtika FKIP Universitas Tamansiswa Palembang \\ *malalina@unitaspalembang.ac.id
}

\begin{abstract}
The formulation of the problem in this research is the application of snakes and ladders media on the material width and circumference of a triangle. The subjects of this study were 37 seventh grade students in Tamansiswa Middle School Palembang. Data collehction techniques are observation and tests. The test instruments used in this study were tested for validity, reliability, level of difficulty and distinguishing features. The data analysis technique used is average. The conclusion of this study is the application of the media snake ladder of the circumference and area of the triangle that is getting an average of 85.07, this states that student learning outcomes after applied the snake ladder game can be categorized well.
\end{abstract}

Key Words: Medium, Triangle, Snakes and Ladders

Abstrak: Rumusan masalah dalam penelitian ini adalah Penerapan media ular tangga pada materi luas dan keliling segitiga. Subjek penelitian ini adalah siswa kelas VII sebanyak 37 siswa di SMP Tamansiswa Palembang. Teknik pengumpulan data adalah observasi dan tes. Instrumen tes yang digunakan dalam penelitian ini dengan dilakukan uji validitas, reliabilitas, tingkat kesukaran dan daya pembeda. Teknik analisis data yang digunakan adalah rata-rata. Kesimpulan penelitian ini adalah penerapan media ular tangga materi keliling dan luas segitiga yaitu mendapatkan rata-rata 85,07, hal ini menyatakan bahwa hasil belajar siswa setalah diterapkan permainan ular tangga dapat dikategorikan baik.

Kata Kunci: Media, Segitiga, Ular Tangga

PENDAHULUAN

Peradaban suatu bangsa hanya dapat dibangun melalui pendidikan sehingga dengan pendidikan dapat membangun sumber daya manusia. Negara yang bermutu adalah negara yang memiliki pendidikan yang bermutu (Shoimin, 2014). Meningkatkan pendidikan yang bermutu dapat dilakukan melalui pembelajaran matematika. Pembelajaran matematika perlu mendapatkan perhatian dalam menentukan strategi yang digunakan dalam pembelajaran matematika. Pembelajaran matematika dipelajari dari jenjang sekolah dasar sampai perguruan tinggi.

Pembelajaran matematika belum sesuai dengan yang diharapkan, banyak 
faktor yang membuat pembelajaran matematika belum sesuai, salah satunya media pembelajaran yang digunakan. Selain itu, berdasarkan observasi awal didapatkan bahwa peserta didik sulit mengingat rumusrumus matematika, siswa mempunyai anggapan bahwa pelajaran matematika itu sulit dan tidak menyenangkan. Sehingga peran guru sangat dibutuhkan untuk merubah anggapan siswa terhadap matematika yaitu dengan penggunaan media pembelajaran.

Media dapat membangun kondisi siswa sehingga mampu memperoleh pengetahuan, keterampilan atau sikap menggunakan materi (Arsyad, 2009). Media pembelajaran yang digunakan dalam penelitian ini adalah media pembelajaran ular tangga. Ular tangga yang dikembangkan dalam penelitian ini merupakan salah satu permainan tradisional yang bisa dimainkan oleh siapapun.

Penggunaan media ular tangga dapat meningkatkan hasil belajar (Irawan \& Wardani, 2016). Media ular tangga dalam pembelajaran matematika dapat meningkatkan motivasi siswa (Marta et al., 2017).

Rumusan masalah dalam penelitian ini adalah Penerapan media ular tangga pada materi luas dan keliling segitiga.

\section{TINJAUAN TEORETIS}

Permainan ular tangga adalah papan yang digunakan untuk bermain yang dibagi menjadi kotak-kotak kecil dan dibeberapa kotak digambarkan sejumlah ular dan tangga yang menghubungkan dengan kotak lainnya.
Aturan permainan ular tangga yaitu :

- Kelompok terdiri dari 2-4 orang

- Memilih urutan siapa yang bermain terdahulu

- Pemain akan maju sesuai dengan angka pada dadu yang didapatkan

- Setiap pemain harus menjawab pertanyaan pada ular tangga

- Jika pemain bisa menjawab benar maka, akan tetap berada di tempat. Jika salah maka akan kembali ke tempat semula

- Waktu yang dibutuhkan dalam satu kali permainan adalah 15 menit

- Pemain yang mencapai garis finish adalah pemain yang menang.

\section{METODOLOGI PENELITIAN}

Sampel penelitian ini adalah siswa kelas VII sebanyak 37 siswa di SMP Tamansiswa Palembang. Teknik pengumpulan data adalah observasi dan tes. Instrumen tes yang digunakan dalam penelitian ini adalah dengan melakukan uji validitas, reliabilitas, tingkat kesukaran dan daya pembeda. Teknik analisis data yang digunakan adalah rata-rata.

\section{HASIL DAN PEMBAHASAN}

Penelitian ini terdiri empat kali pertemuan yaitu sebagai berikut :

Pertemuan pertama dilakukan pretest terlebih dahulu dengan menggunakan 4 soal essay.

Pertemuan kedua menjelaskan materi tentang keliling segitiga. Siswa dibagi menjadi 8 kelompok dengan satu kelompok terdiri dari 4-5 siswa. Guru menjelaskan peraturan permainan ular tangga. Guru membantu siswa 
yang mengalami kesulitan dalam bermain ular tangga. Dari pertemuan kedua, dapat dinyatakan bahwa siswa aktif dalam pembelajaran dengan menggunakan media pembelajaran ular tangga serta siswa antusias dalam bermain ular tangga. Observasi yang dilakukan menyatakan bahwa siswa dapat menyelesaikan persoalan keliling segitiga serta memahami rumus keliling segitiga.

Pertemuan ketiga menjelaskan materi luas segitga. Sama seperti pada pertemuan kedua, siswa tidak mengalami kendala dalam permainan ular tangga.

Pertemuan keempat dengan melaksanakan posttest untuk mengukur kemampuan hasil belajar siswa pada pembelajaran matematika setelah dilaksanakan pembelajaran dengan menggunakan media ular tangga.

Analisis hasil observasi yang digunakan dalam penelitian ini menggunakan tiga indikator yaitu aktivitas visual, lisan, dan menulis. Adapun tujuan indikator ini adalah untuk mengetahui peningkatan aktivitas peserta didik dalam penggunaan media ular tangga. Hasil observasi disajikan pada tabel 1 berikut

Tabel 1 Rata-rata Observasi

\begin{tabular}{|c|c|}
\hline Indikator & Rata-rata \\
\hline Visual & 66,22 \\
\hline Lisan & 63,51 \\
\hline Menulis & 75,23 \\
\hline
\end{tabular}

Aktivitas visual meliputi: siswa dapat membaca materi dengan baik, memperhatikan penjelasan guru dan siswa mengikuti petunjuk penggunaan permainan ular tangga. Aktivitas lisan meliputi siswa mengajukan pertanyaan, berdiskusi dan mengemukakan pendapat. Aktivitas menulis adalah mengerjakan soal.

Dalam penelitian yang dilakukan, indikator yang paling dominan adalah indikator menulis. Hal ini dikarenakan siswa senang menggunakan media ular tangga untuk belajar dan menjawab soal dan mencari jawaban soal yang ada pada media ular tangga. Indikator lisan merupakan nilai hanya mendapat 63,51. Hal ini dikarenakan siswa kurang percaya diri dalam memberikan tanggapan jawaban lain.

Tes yang dilakukan dalam penelitian ini yaitu pretest dan posttest mengunakan 4 soal berbentuk essay dengan mengunakan materi keliling dan luas segitiga.

Tabel 2. Hasil Pretest dan Posttest

\begin{tabular}{|c|c|c|c|}
\hline Nilai & Kategori & $\begin{array}{c}\text { Frekuensi } \\
\text { Prestest }\end{array}$ & $\begin{array}{c}\text { Frekuensi } \\
\text { Posttest }\end{array}$ \\
\hline $86-100$ & $\begin{array}{c}\text { Baik } \\
\text { Sekali }\end{array}$ & 0 & 20 \\
\hline $71-85$ & Baik & 2 & 12 \\
\hline $56-70$ & Cukup & 18 & 5 \\
\hline $41-55$ & Kurang & 17 & 0 \\
\hline \multicolumn{2}{|c|}{ Rata-rata } & 56,39 & 85,07 \\
\hline
\end{tabular}

Berdasarkan tabel 2 didapatkan ratarata pretest dengan nilai 56,39 dan ratarata skor siswa hasil posttest sebanyak 37 siswa adalah 85,07. Hal ini menyatakan bahwa hasil belajar matematika dengan materi keliling dan luas segitia dengan kategori baik.

\section{SIMPULAN DAN SARAN}

Penerapan media ular tangga materi keliling dan luas segitiga yaitu mendapatkan rata-rata 85,07. Hal ini menyatakan bahwa hasil belajar siswa 
setelah diterapkan permainan ular tangga dapat dikategorikan baik.

\section{DAFTAR PUSTAKA}

Arsyad, A. (2009). Media Pembelajaran. Rajawali Pers.

Irawan, A., \& Wardani, M. A. (2016). Meningkatkan Hasil Belajar Matematika Siswa Dengan Menggunakan Permainan Ular Tangga Pada Tingkat Sekolah Menengah Pertama. Jurnal Inovasi Dan Teknologi Pembelajaran, 1(4), 338-348.

Marta, F. N., Supriadie, D., \& Susilana, Rudi. (2017). Pengaruh Penerapan Model Pembelajaran Kooperatif Tipe Teams Games Tournaments Berbantuan Media Permainan Ular Tangga Terhadap Peningkatan Motivasi Belajar Siswa. EDUTCEHNOLOGIA, 3(3).

Shoimin, A. (2014). Metode Pembelajaran Inovatif Dalam Kurikulum 2013. Ar-Ruzz Media. 